\title{
Metastatic Colon Carcinoma
}

National Cancer Institute

\section{Source}

National Cancer Institute. Metastatic Colon Carcinoma. NCI Thesaurus. Code C156097.

A carcinoma that arises from the colon and has metastasized to another anatomic site. 